\title{
Importance and Prospects for Design of Selective Muscarinic Agonists
}

\author{
J. JAKUBÍK, P. MICHAL, E. MACHOVÁ, V. DOLEŽAL \\ Department of Neurochemistry, Institute of Physiology, Czech Academy of Sciences, v.v.i, Prague, \\ Czech Republic
}

Received February 15, 2008

Accepted April 16, 2008

On-line May 13, 2008

\begin{abstract}
There are five subtypes of muscarinic receptors that serve various important physiological functions in the central nervous system and the periphery. Mental functions like attention, learning, and memory are attributed to the muscarinic $M_{1}$ subtype. These functions decline during natural aging and an early deficit is typical for Alzheimer's disease. In addition, stimulation of the $M_{1}$ receptor increases non-amyloidogenic processing of the amyloid precursor protein and thus prevents accumulation of noxious $\beta$-amyloid fragments. The selectivity of classical muscarinic agonists among receptor subtypes is very low due to the highly conserved nature of the orthosteric binding site among receptor subtypes. Herein we summarize some recent studies with the functionally-selective $M_{1}$ agonist xanomeline that indicate complex pharmacological profile of this drug that includes interactions with and activation of receptor from both orthosteric and ectopic binding sites, and the time-dependent changes of ligand binding and receptor activation. These findings point to potential profitability of exploitation of ectopic ligands in the search for truly selective muscarinic receptor agonists.
\end{abstract}

\section{Key words}

Cholinergic transmission - Xanomeline - Muscarinic receptor subtypes $\bullet$ G-proteins activation $\bullet$ Ectopic agonists

\section{Corresponding author}

V. Doležal, Department of Neurochemistry, Institute of Physiology, Academy of Sciences of the Czech Republic, Vídeňská 1083, 14220 Prague 4, Czech Republic. Fax: +(420) 296442488.

E-mail: dolezal@biomed.cas.cz

\section{Introduction}

Cholinergic neurons serve important functions both in the periphery and the central nervous system. Signals from presynaptic cholinergic terminal mediated by released acetylcholine (ACh) are transmitted to postsynaptic cells through two types of acetylcholine receptors, nicotinic and muscarinic. Nicotinic ACh receptors are non-selective cation channels whose activation leads to depolarization of postsynaptic cells. They are heteropentamers assembled from $\alpha, \beta, \gamma, \delta$, and $\varepsilon$ subunits or in the case of certain central nicotinic receptors homopentamers composed of specific $\alpha$-subunits only (Gotti et al. 2006). Muscarinic receptors belong to a family of GTP binding protein (G-protein)coupled receptors that together represent the largest family of plasma membrane receptors (Lander et al. 2001, Fredriksson et al. 2003). Their stimulation leads to activation of specific G-proteins that transduce extracellular mediator messages to specific intracellular signaling pathways. A common feature of all G-proteincoupled receptors is that they are single proteins that comprise seven transmembrane domains. To date five subtypes of muscarinic receptors denoted as $\mathrm{M}_{1}-\mathrm{M}_{5}$ and encoded by five different genes have been discovered (Bonner et al. 1987, 1988, Peralta et al. 1987, Bonner 1989a,b).

Muscarinic and nicotinic receptors are widely expressed in both the central nervous system and in the periphery with distinct cellular as well as tissue localization of individual subtypes. Within the central nervous system, cholinergic neurotransmission is of utmost importance for mental functions such as learning, memory, and attention. The efficiency of mental functions becomes impaired during normal aging and this impairment has generally been ascribed to decreases in nerve cell number. Recent studies on primates and other mammals indicate, however, that atrophy of cholinergic 
neurons in the basal forebrain may be more important for the impairment of mental functions than the comparatively small diminution of the total neuronal population in the brain (Smith et al. 1999, Conner et al. 2001, review Morrison and Hof 1997). Impaired neurotransmission via cholinergic synapses involves diminished release of acetylcholine, attenuation of the response of postsynaptic cells, and decreased density of the cholinergic innervation of the brain cortex and hippocampus. Recent studies indicate that the atrophy of basal forebrain cholinergic neurons is reversible (Smith et al. 1999, Conner et al. 2001). Loss of different types of neurons accompanied by deterioration of neural functions is known to occur in a number of neurodegenerative conditions such as Parkinson's disease, Alzheimer's disease, Huntington's disease, Wilson's disease and others. The reasons why certain groups of neurons degenerate, as well as the pathogenetic mechanisms responsible for the degeneration are not clear (reviewed in Sarter and Bruno 1998, 2004, Mehler and Gokhan 2000, 2001).

\section{Roles of brain muscarinic receptors}

As mentioned above, cholinergic transmission plays an important role in mental functions like attention, learning, and memory. These functions decline in the course of natural aging and accelerated deficit of cognitive functions is a typical symptom of Alzheimer's disease. At present, Alzheimer's disease is the most common neurodegenerative disease of the central nervous system whose incidence increases steadily. Original neurochemical findings of disturbances of acetylcholine metabolism (Bowen et al. 1976, Davies and Maloney 1976, Perry et al. 1977a,b, Sims et al. 1981, Francis et al. 1985) became basis for the „cholinergic hypothesis“ of Alzheimer's disease (Bartus et al. 1982, Francis et al. 1999, Doležal and Kašparová 2003, Mesulam 2004). Since then a large body of evidence both supporting and questioning this hypothesis has accumulated (Bartus 2000).

One of the most important issues is whether disturbances of cholinergic mechanisms are present early in the pathogenesis of Alzheimer's disease or are simply a reflection of a general neurodegeneration that afflicts many neurotransmitter systems in the late or terminal stage of the disease. This issue is crucial for designing potential therapeutic approaches. In addition to the involvement of brain muscarinic transmission in mental functions it was demonstrated that stimulation of $\mathrm{M}_{1}$ and $\mathrm{M}_{3}$ subtypes of muscarinic receptors leads to nonamyloidogenic cleavage of the amyloid precursor protein (Buxbaum et al. 1992, Nitsch et al. 1992), leading to decreased production of noxious beta-amyloid fragments responsible for disease genesis and progression. The attenuation of muscarinic transmission early in pathogenesis of the disease may thus result in accelerated progression of the disease or could even participate as the primary insult in some of nonhereditary cases of the disease (Meier-Ruge 1994, 1996, Messier and Gagnon 1996, Hoyer 2000). Involvement of muscarinic receptors in regulation of the production of $\beta$-amyloid in human is further supported by the observation of its increased accumulation in Parkinson's disease patients treated with antimuscarinic drugs (Perry et al. 2003). Additional support for muscarinic receptor signaling involvement comes from recent findings of early impairment of muscarinic receptor-G-protein coupling in a transgenic mice model of Alzheimer's disease (Machová et al. 2008) correlating with the increase of amyloid- $\beta_{1-42}$ production (Savonenko et al. 2005) and the attenuation of $\mathrm{M}_{1}$ receptor activation in Alzheimer's brain cortex obtained at autopsy in human (Tsang et al. 2005).

\section{Possibilities of muscarinic receptor subtype- specific interventions}

Given the broad range of functions that muscarinic receptor subserve, it is of fundamental importance to find subtype-selective ligands for therapeutic use in specific disorders. Selectivity of physiological stimulation of muscarinic receptors is provided by the tissue localization of nerve endings and the firing pattern of cholinergic neurons. In contrast, exogenous ligands access all muscarinic receptors equally. Muscarinic receptors have a classical (orthosteric) binding site for natural or exogenous ligands located deep in a pocket created by the transmembrane segments of the receptor protein. This site is highly conserved among individual muscarinic receptor subtypes (Hulme et al. 2003). Some muscarinic antagonists display good subtype selectivity as their relatively bulky structure allows them to interact with less conserved amino acids adjacent to the orthosteric binding domain. In contrast, orthosteric agonists generally show poor selectivity as they are usually small and interact solely with few key amino acids in the conserved orthosteric binding site. 


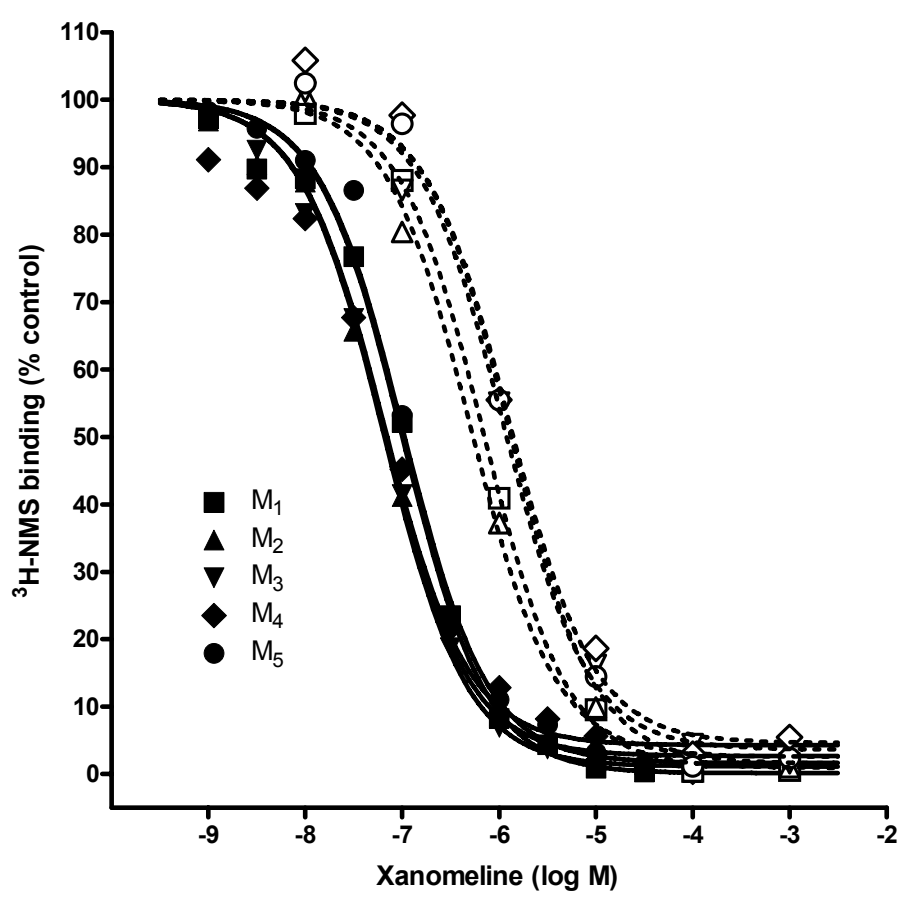

Fig. 1. Interactions of xanomeline with muscarinic receptor subtypes. Upper panel: Displacement of $1 \mathrm{nM}\left[{ }^{3} \mathrm{H}\right]-\mathrm{N}-$ methylscopolamine binding by the indicated concentrations of xanomeline (abscissa, log M) when present together with xanomeline (closed symbols) or after preincubation with the indicated concentrations of xanomeline followed by washing in the absence of free drug (open symbols). Data are derived from experiments performed on receptors expressed in membranes of $\mathrm{CHO}$ cells (Jakubík et al. 2006, Machová et al. 2007). Ordinate, specific $\left[{ }^{3} \mathrm{H}\right]-\mathrm{N}$-methylscopolamine binding is expressed as percent of control binding in the absence of xanomeline treatment. Lower panel: $\mathrm{IC}_{50}$ of reversible and wash-resistant xanomeline binding.

\begin{tabular}{|c|c|c|c|c|c|}
\hline & \multicolumn{5}{|c|}{$\mathrm{IC}_{50}(\log \mathrm{M})$} \\
\hline receptor subtype & $\mathrm{M}_{1}$ & $\mathrm{M}_{2}$ & $\mathrm{M}_{3}$ & $\mathrm{M}_{4}$ & $\mathrm{M}_{5}$ \\
\hline reversible binding & $-7.00+/-0.04$ & $-7.19+/-0.03$ & $-7.19+/-0.02$ & $-7.19+/-0.06$ & $-6.99+/-0.02$ \\
\hline $\begin{array}{c}\text { wash-resistant } \\
\text { binding }\end{array}$ & $-6.16+/-0.02$ & $-6.29+/-0.05$ & $-5.95+/-0.06$ & $-5.89+/-0.09$ & $-5.89+/-0.05$ \\
\hline
\end{tabular}

There are several possibilities for subtypespecific modulation of muscarinic transmission. A high degree of muscarinic receptor subtype selectivity can be achieved using allosteric modulators that increase or decrease affinity of classical agonists and antagonists including the natural ligand ACh. A large number of such allosteric ligands has been described (Tuček et al. 1990, Proška and Tuček 1994, Jakubík et al. 1995, 1997, Lazareno and Birdsall 1995, Doležal and Tuček 1998, Tuček et al. 1990, 1998, Lazareno et al. 2004, Jager et al. 2007). It has also been shown that allosteric modulators can directly induce activation of G-proteins in the absence of agonists (Jakubík et al. 1996, 1998). However, this type of activation is much less efficacious than that induced by full orthosteric agonists and is not prevented by the muscarinic antagonist atropine.

Still another type of muscarinic agonists exhibiting "functional selectivity" has recently been described. These particular ligands are represented by xanomeline (3-[3-hexyloxy-1,2,5-thiadiazo-4-yl]-1,2,5,6tetrahydro-1-methylpyridine; Shannon et al. 1994, Bymaster et al. 1994, 1998) and AC-42 (4-n-butyl-1-[4(2-methylphenyl)-4-oxo-1-butyl]-piperidine; Spalding et al. 2002, Langmead et al. 2006). They bind with comparable affinity to the orthosteric binding site of all subtypes of muscarinic receptors but in functional assays activate mainly the $\mathrm{M}_{1}$ subtype with efficacy comparable to that of classical full agonists. Their functional outcome of receptor activation is prevented by atropine. It has been proposed that these atypical agonists attach to additional less conserved "ectopic" sites that are important for receptor activation.

\section{Mechanisms of xanomeline action}

Ectopic agonists thus represent a new class of muscarinic agonists that display functional selectivity. However, the molecular mechanisms determining this unique pharmacological profile are not known. We have recently been studying binding characteristics of xanomeline. Experiments revealed that it associates with $\mathrm{M}_{1}$ receptors in an unusual way. Xanomeline displays two substantially different modes of binding; reversible binding with the orthosteric binding site and washresistant binding with a half-life more than 30 hours that takes place somewhere else (Jakubík et al. 2002). Reversibly as well as persistently bound xanomeline stimulates $M_{1}$ receptors and increases accumulation of 


\section{CHO membranes: $M_{2}$ receptors}

\section{CHO membranes: $M_{1}$ receptors}

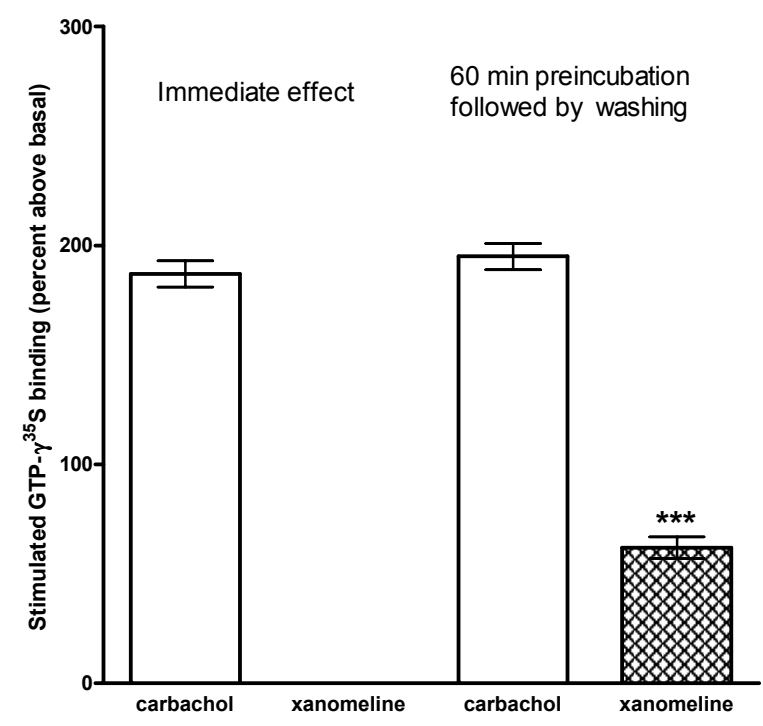

Cortex: $M_{2}$ receptors

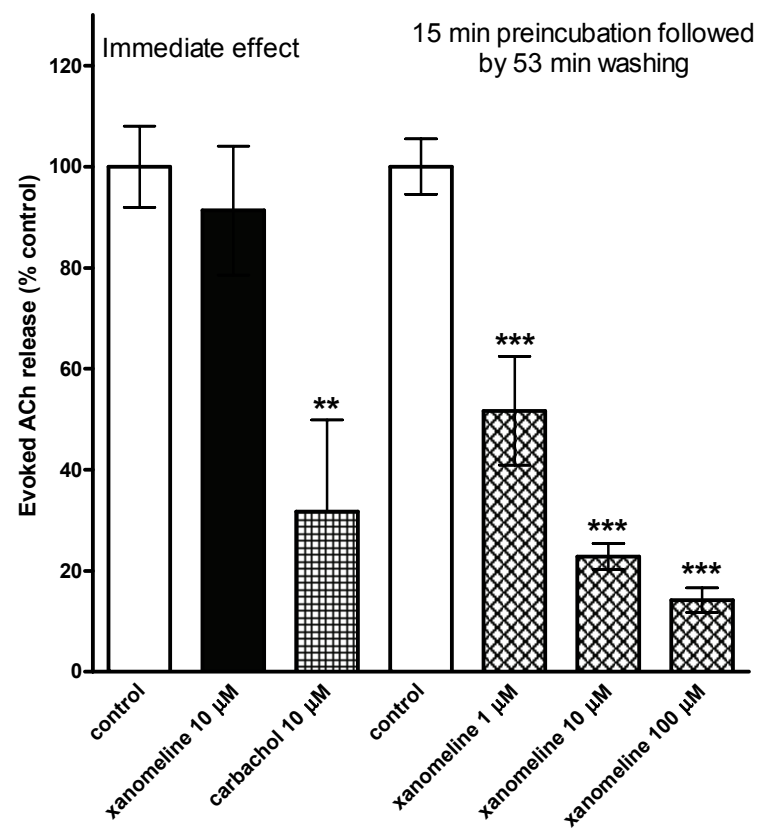

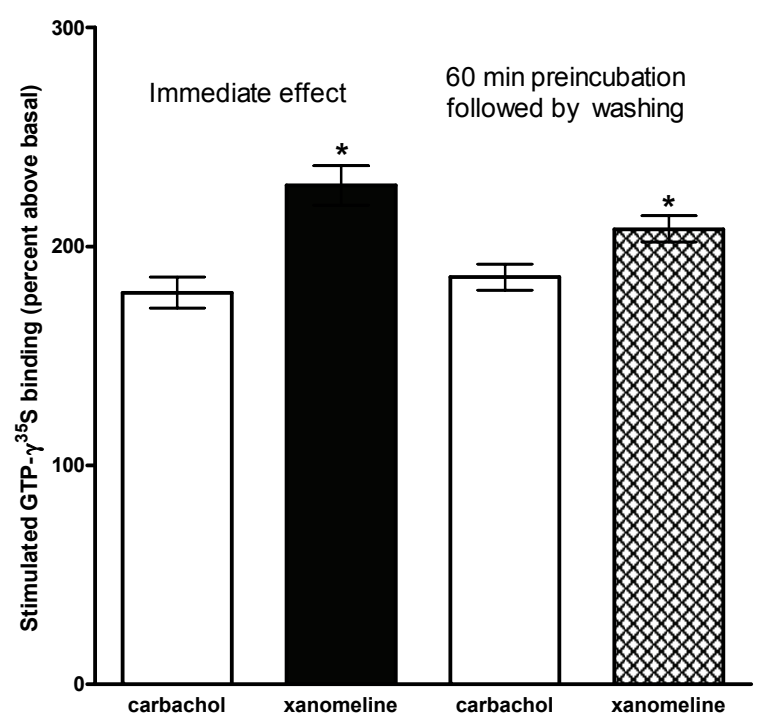

Striatum: $\mathrm{M}_{4}$ receptors

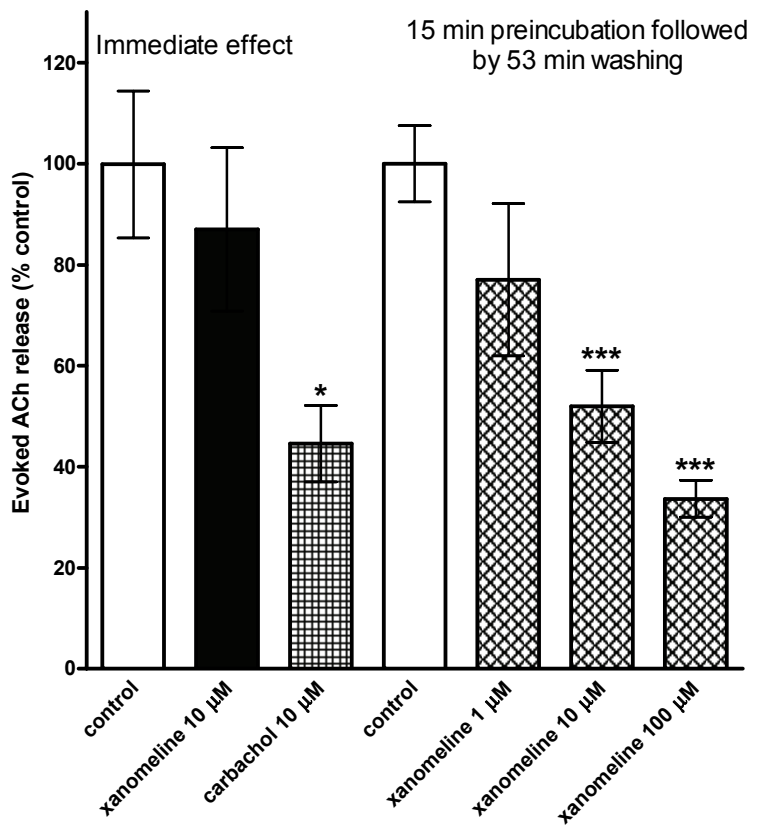

Fig. 2. Effects of free and wash-resistantly bound xanomeline in functional tests. Upper row: $A t M_{2}$ receptors (left) expressed in CHO membranes immediate application of xanomeline does not stimulate GTP- $\gamma S$ binding. Significant stimulation amounting about one third of that induced by carbachol occurs after 60 min preincubation and removal of free xanomeline. Both free and wash-resistantly bound xanomeline at $M_{1}$ receptors stimulate GTP- $y S$ binding to a similar extent that is significantly bigger than that induced by carbachol. Ordinate: values of induced increase of GTP-yS binding expressed as percent increase above basal values are derived from concentration-response measurements (Jakubík et al. 2006). $\mathrm{EC}_{50}$ values (log $\mathrm{M}$ ) for carbachol are 6.12 and 6.06 at $\mathrm{M}_{2}$ receptors and 6.08 , and 6.07 at $M_{1}$ receptors without or with preincubation in the presence of carbachol, respectively. $\mathrm{EC}_{50}$ values for xanomeline are no effect and 5.81 at $M_{2}$ receptors and 8.04 and 5.98 at $M_{1}$ receptors without or with preincubation in the presence of xanomeline, respectively. Asterisks indicate significant difference from corresponding values in the presence of carbachol by $\mathrm{t}$-test. Lower row: Unlike carbachol $(10 \mu \mathrm{M})$ immediate application of xanomeline $(10 \mu \mathrm{M})$ does not stimulate presynaptic inhibitory autoreceptors either in cortex ( $M_{2}$ receptors; left graph) or in striatum ( $M_{4}$ receptors; right graph). Significant concentration-dependent inhibition of stimulated ACh release becomes apparent after 15 min preincubation followed by 53 minutes washing, i.e. in the absence of free xanomeline (Machová et al. 2007). Ordinate: evoked ACh release is expressed as percent of control release in the absence of drugs. Asterisks indicate significant difference from corresponding controls determined by ANOVA and Dunnet's test. 
inositolphosphates in a classical antagonist-sensitive manner. However, xanomeline persistent binding can form even in the presence of orthosteric antagonists. The wash-resistant binding depends on the length of the $\mathrm{O}$ alkyl chain of xanomeline which has to be at least $\mathrm{O}$ butyl or longer (Jakubík et al. 2004). Only the reversible binding of xanomeline was detected on purified soluble receptors but both binding modes occurred on purified receptors reconstituted into liposomes. Wash-resistant binding appeared only when receptors were exposed to xanomeline after, but not before, reconstitution. These results indicate that the wash-resistant binding of xanomeline involves interhelical penetration of O-alkyl chain and its interaction with membrane lipids surrounding the receptor. However, this wash-resistant binding to the $M_{1}$ receptor as such cannot underlie functional selectivity of xanomeline because we demonstrated that it occurs with comparable affinity at all subtypes of muscarinic receptors (Jakubík et al. 2006, Machová et al. 2007; Fig. 1).

Kinetic and functional experiments on $\mathrm{M}_{1}$ and $\mathrm{M}_{2}$ receptors expressed in membranes of $\mathrm{CHO}$ cells revealed conspicuous differences in kinetics of washresistant xanomeline binding and receptor activation (Jakubík et al. 2006). The rate of formation of washresistant xanomeline binding is faster at $M_{1}$ than $M_{2}$ receptors at concentrations up to $3 \mu \mathrm{M}$ but in either case does not correspond to a simple bimolecular reaction. Most remarkable xanomeline displays instant washresistant binding at $\mathrm{M}_{1}$, but not $\mathrm{M}_{2}$ receptors. In line with functional $\mathrm{M}_{1}$ selectivity, xanomeline application immediately increases GTP- $\gamma \mathrm{S}$ binding (indicator of receptor activation) with higher potency and efficacy than the classical full agonist carbachol whereas it has no effect at $\mathrm{M}_{2}$ receptors (Fig. 2). Both free and washresistantly bound xanomeline activate $M_{1}$ receptor to a similar extent but with about 100 times lesser potency in the case of wash-resistant xanomeline (in the absence of free ligand). At $\mathrm{M}_{2}$ receptors, unlike immediate application, wash-resistant xanomeline stimulates GTP$\gamma \mathrm{S}$ binding both in the absence and presence of free ligand to a similar extent that is, however, only about one third of the activation induced by carbachol (Fig. 2). Similar to the $\mathrm{M}_{1}$ subtype, the potency is about 100 times higher in the presence of free ligand. Individual muscarinic receptor subtypes prefer coupling with specific G-proteins but agonist stimulation can also induce (although with lower potency and efficacy) activation of other G-proteins (Michal et al. 2001). The
$\mathrm{M}_{2}$ receptor subtype directly couples with all three major G-protein subclasses, i.e. $\mathrm{G}_{\mathrm{i} / \mathrm{o}}$ (preferential), $\mathrm{G}_{\mathrm{s}}$, and $\mathrm{G}_{\mathrm{q} / 11}$ (Michal et al. 2007). Wash resistantly bound xanomeline at $\mathrm{M}_{2}$ receptors and both free and wash-resistant xanomeline at $\mathrm{M}_{1}$ receptors activate coupling of preferential $\left(\mathrm{G}_{\mathrm{i} / \mathrm{o}}\right.$ and $\left.\mathrm{G}_{\mathrm{q} / 11}\right)$ but also of non-preferential G-proteins. Discrimination by xanomeline among preferential and non-preferential G-proteins is better at $\mathrm{M}_{1}$ than $\mathrm{M}_{2}$ subtype.

These observations further support the concept of agonist-induced formation of multiple receptor conformations and emphasize the importance of kinetics of ligand binding and receptor activation in subtype selectivity. However, the above observations were derived from studies on receptors heterologously expressed in Chinese hamster ovary (CHO) cells. Applicability of these results to naturally expressed muscarinic receptors were demonstrated in ex vivo experiments with native tissue. Evoked ACh release from rat cortical and striatal slices is autoinhibited by presynaptic $\mathrm{M}_{2}$ and $\mathrm{M}_{4}$ receptors (Doležal and Tuček 1998, Zhang et al. 2002) that mediate this effect via the $\beta \gamma$ dimer of the pertussis toxin-sensitive G-proteins $\mathrm{G}_{\mathrm{i} / \mathrm{o}}$ (Doležal et al. 1989, Herlitze 1996). In line with reported $\mathrm{M}_{1}$ selectivity, immediate application of xanomeline has no effect on the evoked $\mathrm{ACh}$ release in rat cortex or striatum. In contrast, short preincubation with xanomeline followed by extensive washing in both tissues results in a concentration-dependent permanent inhibition of evoked ACh release that amounts to the maximal inhibition achievable by the full agonist carbachol (Machová et al. 2007; Fig. 2). Inhibitory effects of wash-resistant xanomeline could not be abolished either by extensive washing in the presence of a classical antagonist, by the presence of antagonist during xanomeline treatment, or by irreversible blockade of the orthosteric binding site before xanomeline treatment. Delayed inhibitory effects of xanomeline treatment on evoked $\mathrm{ACh}$ release at concentrations up to $10 \mu \mathrm{M}$ is fully antagonized by an orthosteric antagonist present during stimulation. However, inhibition of evoked $\mathrm{ACh}$ release after treatment with $100 \mu \mathrm{M}$ is only partially sensitive to antagonist indicating receptor activation from an ectopic site.

\section{Conclusions}

Xanomeline demonstrates a complex pharmacological profile that involves reversible and 
wash-resistant binding that results in full agonist activity at the $\mathrm{M}_{1}$ muscarinic receptor or delayed wash-resistant partial agonist activity at $\mathrm{M}_{2}$ receptors, or delayed washresistant full agonist activity at $\mathrm{M}_{2}$ and $\mathrm{M}_{4}$ receptors in native brain tissue. This complex profile that includes interactions with and activation of the receptor from both orthosteric and ectopic binding sites, and the timedependent changes of ligand binding and receptor activation point to potential profitability of exploiting ectopic ligands in search for muscarinic receptor subtypeselective drugs.

\section{Conflict of Interest}

There is no conflict of interest.

\section{Acknowledgements}

The authors would like to appreciate the most valuable help of Prof. E.E. El-Fakahany with preparation of the manuscript. This work was supported by project AV0Z50110509, grants of Ministry of Education LC554, GACR305/05/P209, and GACR305/05/0452.

\section{References}

BARTUS RT: On neurodegenerative diseases, models, and treatment strategies: lessons learned and lessons forgotten a generation following the cholinergic hypothesis. Exp Neurol 163: 495-529, 2000.

BARTUS RT, DEAN RL, BEER B, LIPPA AS: The cholinergic hypothesis of geriatric memory dysfunction. Science 217: 408-414, 1982.

BONNER TI: New subtypes of muscarinic acetylcholine receptors. Trends Pharmacol Sci Suppl: 11-15, 1989a.

BONNER TI: The molecular basis of muscarinic receptor diversity. Trends Neurosci 12: 148-151, $1989 \mathrm{~b}$.

BONNER TI, YOUNG AC, BRANN MR, BUCKLEY NJ: Cloning and expression of the human and rat m5 muscarinic acetylcholine receptor genes. Neuron 1: 403-410, 1988.

BONNER TI, BUCKLEY NJ, YOUNG AC, BRANN MR: Identification of a family of muscarinic acetylcholine receptor genes. Science 237: 527-532, 1987.

BOWEN DM, SMITH CB, WHITE P, Davison AN: Neurotransmitter-related enzymes and indices of hypoxia in senile dementia and other abiotrophies. Brain 99: 459-496, 1976.

BUXBAUM JD, OISHI M, CHEN HI, PINKAS-KRAMARSKI R, E. A. JAFFE EA, GANDY SE, GREENGARD P: Cholinergic agonists and interleukin 1 regulate processing and secretion of the Alzheimer beta/A4 amyloid protein precursor. Proc Natl Acad Sci USA 89: 10075-10078, 1992.

BYMASTER FP, WONG DT, MITCH CH, WARD JS, CALLIGARO DO, SCHOEPP DD, SHANNON HE, SHEARDOWN MJ, OLESEN PH, SUZDAK PD: Neurochemical effects of the $\mathrm{M}_{1}$ muscarinic agonist xanomeline (LY246708/NNC11-0232). J Pharmacol Exp Ther 269: 282-289, 1994.

BYMASTER FP, CARTER PA, PETERS SC, ZHANG W, WARD JS, MITCH CH, CALLIGARO DO, WHITESITT CA, DELAPP N, SHANNON HE, RIMVALL K, JEPPESEN L, M. SHEARDOWN MJ, FINK-JENSEN A, SAUERBERG P: Xanomeline compared to other muscarinic agents on stimulation of phosphoinositide hydrolysis in vivo and other cholinomimetic effects. Brain Res 795: 179-190, 1998.

CONNER JM, DARRACQ MA, ROBERTS J, M. H. TUSZYNSKI MH: Nontropic actions of neurotrophins: subcortical nerve growth factor gene delivery reverses age-related degeneration of primate cortical cholinergic innervation. Proc Natl Acad Sci USA 98: 1941-1946, 2001.

DAVIES P, MALONEY AJ: Selective loss of central cholinergic neurons in Alzheimer's disease. Lancet 2: 1403 , 1976. DOLEŽAL V, KAŠPAROVÁ J: Beta-amyloid and cholinergic neurons. Neurochem Res 28: 499-506, 2003.

DOLEŽAL V, TUČEK S: The effects of brucine and alcuronium on the inhibition of ${ }^{3} \mathrm{H}$ acetylcholine release from rat striatum by muscarinic receptor agonists. Br J Pharmacol 124: 1213-1218, 1998.

DOLEŽAL V, TUČEK S, HYNIE S: Effects of pertussis toxin suggest a role for G-proteins in the inhibition of acetylcholine release from rat myenteric plexus by opioid and presynaptic muscarinic receptors. Eur $J$ Neurosci 1: 127-131, 1989.

FRANCIS PT, PALMER AM, SNAPE M, WILCOCK GK: The cholinergic hypothesis of Alzheimer's disease: a review of progress. J Neurol Neurosurg Psychiatry 66: 137-147, 1999. 
FRANCIS PT, PALMER AM, SIMS NR, BOWEN DM, DAVISON AN, ESIRI MM, NEARY D, SNOWDEN JS, WILCOCK GK: Neurochemical studies of early-onset Alzheimer's disease. Possible influence on treatment. N Engl J Med 313: 7-11, 1985.

FREDRIKSSON R, LAGERSTROM MC, LUNDIN LG, SCHIOTH HB. The G-protein-coupled receptors in the human genome form five main families. Phylogenetic analysis, paralogon groups, and fingerprints. Mol Pharmacol 63: 1256-1272, 2003.

GOTTI C, RIGANTI L, VAILATI S, CLEMENTI F: Brain neuronal nicotinic receptors as new targets for drug discovery. Curr Pharm Des 12: 407-428, 2006.

HERLITZE S, GARCIA DE, MACKIE K, HILLE B, SCHEUER T, CATTERALL WA: Modulation of $\mathrm{Ca}^{2+}$ channels by G-protein beta gamma subunits. Nature 380: 258-262, 1996.

HOYER S: Brain glucose and energy metabolism abnormalities in sporadic Alzheimer disease. Causes and consequences: an update. Exp Gerontol 35: 1363-1372, 2000.

HULME EC, LU ZL, SALDANHA JW, BEE MS: Structure and activation of muscarinic acetylcholine receptors. Biochem Soc Trans 31: 29-34, 2003.

JAGER D, SCHMALENBACH C PRILLA S, SCHROBANG J, KEBIG A, SENNWITZ M, HELLER E, TRANKLE C, HOLZGRABE U, HOLTJE HD, MOHR K: Allosteric small molecules unveil a role of an extracellular E2/TM7 junction for GPCR activation. J Biol Chem 282: 34968-34976, 2007.

JAKUBÍK J, BAČÁKOVÁ L, EL-FAKAHANY EE, TUČEK S: Subtype selectivity of the positive allosteric action of alcuronium at cloned $\mathrm{M}_{1}-\mathrm{M}_{5}$ muscarinic acetylcholine receptors. J Pharmacol Exp Ther 274: 1077-1083, 1995.

JAKUBÍK J, BAČÁKOVÁ L, LISÁ V, EL-FAKAHANY EE, TUČEK S: Activation of muscarinic acetylcholine receptors via their allosteric binding sites. Proc Natl Acad Sci USA 93: 8705-8709, 1996.

JAKUBÍK J, BAČÁKOVÁ L, EL-FAKAHANY EE, TUČEK S: Positive cooperativity of acetylcholine and other agonists with allosteric ligands on muscarinic acetylcholine receptors. Mol Pharmacol 52: 172-179, 1997.

JAKUBÍK J, HAGA T, TUČEK S: Effects of an agonist, allosteric modulator, and antagonist on guanosine-gamma$\left.{ }^{35} \mathrm{~S}\right]$ thiotriphosphate binding to liposomes with varying muscarinic receptor $/ \mathrm{G}_{\mathrm{o}}$ protein stoichiometry. Mol Pharmacol 54: 899-906, 1998.

JAKUBÍK J, EL-FAKAHANY EE, DOLEŽAL V: Differences in kinetics of xanomeline binding and selectivity of activation of $g$ proteins at $\mathrm{M}_{1}$ and $\mathrm{M}_{2}$ muscarinic acetylcholine receptors. Mol Pharmacol 70: 656-666, 2006.

JAKUBÍK J, TUČEK S, EL-FAKAHANY EE: Allosteric modulation by persistent binding of xanomeline of the interaction of competitive ligands with the $\mathrm{M}_{1}$ muscarinic acetylcholine receptor. $J$ Pharmacol Exp Ther 301: 1033-1041, 2002.

JAKUBÍK J, TUČEK S, EL-FAKAHANY EE: Role of receptor protein and membrane lipids in xanomeline washresistant binding to muscarinic $\mathrm{M}_{1}$ receptors. J Pharmacol Exp Ther 308: 105-110, 2004.

LANDER ES, LINTON LM, BIRREN B, et al.: Initial sequencing and analysis of the human genome. Nature 409: 860921, 2001.

LANGMEAD CJ, FRY VA, FORBES IT, BRANCH CL, CHRISTOPOULOS A, WOOD MD, HERDON HJ: Probing the molecular mechanism of interaction between 4-n-butyl-1-[4-(2-methylphenyl)-4-oxo-1-butyl]-piperidine (AC-42) and the muscarinic $\mathrm{M}_{1}$ receptor: direct pharmacological evidence that AC-42 is an allosteric agonist. Mol Pharmacol 69: 236-246, 2006.

LAZARENO S, BIRDSALL NJ: Detection, quantitation, and verification of allosteric interactions of agents with labeled and unlabeled ligands at $\mathrm{G}$ protein-coupled receptors: interactions of strychnine and acetylcholine at muscarinic receptors. Mol Pharmacol 48: 362-378, 1995.

LAZARENO S, DOLEŽAL V, POPHAM A, BIRDSALL NJ: Thiochrome enhances acetylcholine affinity at muscarinic $\mathrm{M}_{4}$ receptors: receptor subtype selectivity via cooperativity rather than affinity. Mol Pharmacol 65: 257-266, 2004.

MACHOVÁ E, JAKUBÍK J, EL-FAKAHANY EE, DOLEŽAL V: Wash-resistantly bound xanomeline inhibits acetylcholine release by persistent activation of presynaptic $\mathrm{M}_{2}$ and $\mathrm{M}_{4}$ muscarinic receptors in rat brain. J Pharmacol Exp Ther 322: 316-323, 2007.

MACHOVÁ E, JAKUBÍK J, MICHAL P, OKSMAN M, IIVONEN H, TANILA H, DOLEŽAL V: Impairment of muscarinic transmission in transgenic APPswe/PS1dE9 mice. Neurobiol Aging 29: 368-378, 2008. 
MEHLER MF, GOKHAN S: Developmental mechanisms in the pathogenesis of neurodegenerative diseases. Prog Neurobiol 63: 337-363, 2001.

MEHLER MF, GOKHAN S: Mechanisms underlying neural cell death in neurodegenerative diseases: alterations of a developmentally-mediated cellular rheostat. Trends Neurosci 23: 599-605, 2000.

MEIER-RUGE W, BERTONI-FREDDARI C: The significance of glucose turnover in the brain in the pathogenetic mechanisms of Alzheimer's disease. Rev Neurosci 7: 1-19, 1996.

MEIER-RUGE W, BERTONI-FREDDARI C, IWANGOFF P: Changes in brain glucose metabolism as a key to the pathogenesis of Alzheimer's disease. Gerontology 40: 246-252, 1994.

MESSIER C, GAGNON M: Glucose regulation and cognitive functions: relation to Alzheimer's disease and diabetes. Behav Brain Res 75: 1-11, 1996.

MESULAM M: The cholinergic lesion of Alzheimer's disease: pivotal factor or side show? Learn Mem 11: 43-49, 2004.

MICHAL P, EL-FAKAHANY EE, DOLEŽAL V: Muscarinic $\mathrm{M}_{2}$ receptors directly activate $\mathrm{G}_{\mathrm{q} / 11}$ and $\mathrm{G}_{\mathrm{s}} \mathrm{G}_{-\mathrm{proteins}}$. J Pharmacol Exp Ther 320: 607-14, 2007.

MICHAL P, LYSÍKOVÁ M, TUČEK S: Dual effects of muscarinic $\mathrm{M}_{2}$ acetylcholine receptors on the synthesis of cyclic AMP in CHO cells: dependence on time, receptor density and receptor agonists. Br J Pharmacol 132: 1217-1228, 2001.

MORRISON JH, HOF PR: Life and death of neurons in the aging brain. Science 278: 412-419, 1997.

NITSCH RM, SLACK BE, WURTMAN RJ, GROWDON JH: Release of Alzheimer amyloid precursor derivatives stimulated by activation of muscarinic acetylcholine receptors. Science 258: 304-307, 1992.

PERALTA EG, ASHKENAZI A, WINSLOW JW, SMITH DH, J. RAMACHANDRAN J, CAPON DJ: Distinct primary structures, ligand-binding properties and tissue-specific expression of four human muscarinic acetylcholine receptors. EMBO J 6: 3923-3929, 1987.

PERRY EK, KILFORD L, LEES AJ, BURN DJ, PERRY RH: Increased Alzheimer pathology in Parkinson's disease related to antimuscarinic drugs. Ann Neurol 54: 235-238, 2003.

PERRY EK, GIBSON PH, BLESSED G, PERRY RH, TOMLINSON BE: Neurotransmitter enzyme abnormalities in senile dementia. Choline acetyltransferase and glutamic acid decarboxylase activities in necropsy brain tissue. J Neurol Sci 34: 247-265, 1977a.

PERRY EK, PERRY RH, BLESSED G, TOMLINSON BE: Necropsy evidence of central cholinergic deficits in senile dementia. Lancet 1: 189, 1977 b.

PROŠKA J, TUČEK S: Mechanisms of steric and cooperative actions of alcuronium on cardiac muscarinic acetylcholine receptors. Mol Pharmacol 45: 709-717, 1994.

SARTER M, BRUNO JP: Age-related changes in rodent cortical acetylcholine and cognition: main effects of age versus age as an intervening variable. Brain Res Brain Res Rev 27: 143-156, 1998.

SARTER M, BRUNO JP: Developmental origins of the age-related decline in cortical cholinergic function and associated cognitive abilities. Neurobiol Aging 25: 1127-1139, 2004.

SAVONENKO A, XU GM, MELNIKOVA T, MORTON JL, GONZALES V, WONG MP, PRICE DL, TANG F, MARKOWSKA AL, BORCHLT DR: Episodic-like memory deficits in the APPswe/PS1dE9 mouse model of Alzheimer's disease: relationships to beta-amyloid deposition and neurotransmitter abnormalities. Neurobiol Dis 18: 602-617, 2005.

SHANNON HE, BYMASTER FP, CALLIGARO DO, GREENWOOD B, MITCH CH, SAWYER BD, WARD JS, WONG DT, OLESEN PH, SHEARDOWN MJ:. Xanomeline: a novel muscarinic receptor agonist with functional selectivity for $\mathrm{M}_{1}$ receptors. J Pharmacol Exp Ther 269: 271-281, 1994.

SIMS NR, BOWEN DM, DAVISON AN: $\left[{ }^{14} \mathrm{C}\right]$ acetylcholine synthesis and carbon ${ }^{14} \mathrm{C}$ dioxide production from $\left[\mathrm{U}-{ }^{14} \mathrm{C}\right]$ glucose by tissue prisms from human neocortex. Biochem J 196: 867-876, 1981.

SMITH DE, ROBERTS J, GAGE FH, TUSZYNSKI MH: Age-associated neuronal atrophy occurs in the primate brain and is reversible by growth factor gene therapy. Proc Natl Acad Sci USA 96: 10893-10898, 1999.

SPALDING TA, TROTTER C, SKJAERBAEK N, MESSIER TL, CURRIER EA, BURSTEIN ES, LI D, HACKSELL U, BRANN MR. Discovery of an ectopic activation site on the $\mathrm{M}_{1}$ muscarinic receptor. Mol Pharmacol 61: 1297-1302, 2002. 
TSANG SW, LAI MK, KIRVELL S, FRANCIS PT, ESIRI MM, HOPE T, CHEN CP, WONG PT: Impaired coupling of muscarinic $M_{1}$ receptors to G-proteins in the neocortex is associated with severity of dementia in Alzheimer's disease. Neurobiol Aging 27: 1216-1223, 2005.

TUČEK S, MUSÍLKOVÁ J, NEDOMA J, PROŠKA J, SHELKOVNIKOV S, VORLÍČEK J: Positive cooperativity in the binding of alcuronium and N-methylscopolamine to muscarinic acetylcholine receptors. Mol Pharmacol 38: 674-680, 1990.

TUČEK S, JAKUBÍK J, DOLEŽAL V, EL-FAKAHANY EE: Positive effects of allosteric modulators on the binding properties and the function of muscarinic acetylcholine receptors. $J$ Physiol Paris 92: 241-243, 1998.

ZHANG W, BASILE AS, GOMEZA J, VOLPICELLI LA, LEVEY AI, WESS J: Characterization of central inhibitory muscarinic autoreceptors by the use of muscarinic acetylcholine receptor knock-out mice. J Neurosci 22: 1709$1717,2002$. 